\title{
Perancangan Dan Perhitungan Elemen Mesin Pencetak Pelet Maggot Sistem Extruder
}

\author{
Nuraini Lusi ${ }^{1}$; Ely Trianasari ${ }^{2}$; Aditia Lisda Kusuma ${ }^{3}$; Subhi Lugas Al Hakim ${ }^{4}$ \\ 1,2,3,4 Jurusan Teknik Mesin, Politeknik Negeri Banyuwangi \\ E-mail: nurainilusi@poliwangi.ac.id
}

\begin{abstract}
Abstrak
Biokonversi memang mulai banyak dikembangkan akhir-akhir ini. Melalui proses tersebut, kandungan nutrien yang ada pada sampah organik bisa dibentuk menjadi nutrien bentuk lain yaitu biomassa dengan bantuan larva serangga, salah satunya yaitu larva serangga Hermetia illucens / Black Soldier Fly (BSF). Larva jenis ini sering digunakan sebagai agen biokonversi dan lebih dikenal dengan istilah "maggot". Salah satu contoh pemanfaatannya adalah dalam bentuk pelet maggot. Dari hasil survei yang dilakukan, alat yang digunakan untuk membuat pelet maggot tersebut masih sederhana sehingga menghasilkan pelet yang belum maksimal. Redesain mesin pencetak pelet maggot ini akan mengaplikasikan sistem satu motor untuk penggerak ganda yakni poros extruder dan poros pemotong. Mekanisme kerja mesin pencetak pelet maggot yaitu ketika mesin dinyalakan maka poros screw yang terdapat pada barrel akan berputar sesuai putaran motor dan adonan dari feed hopper turun kebawah masuk kedalam barrel untuk diproses. Adonan yang telah selesai diproses kemudian dikeluarkan melalui cetakan.
\end{abstract}

Kata kunci: biokonversi, maggot, pellet

\begin{abstract}
Bioconversion has indeed begun to be developed a lot recently. Through this process, the nutrient content in organic waste can be formed into other forms of nutrients, namely biomass with the help of insect larvae, one of which is the insect larvae of Hermetia illucens / Black Soldier Fly (BSF). Larvae of this type are often used as bioconversion agents and are better known as "maggots". One example of its use is in the form of maggot pellets. From the results of the survey conducted, the tools used to make maggot pellets are still simple so that they produce pellets that are not optimal. The redesign of this maggot pellet molding machine will apply a single motor system for dual drives, namely the extruder shaft and the cutter shaft. The working mechanism of the maggot pellet molding machine is that when the machine is turned on, the screw shaft in the barrel will rotate according to the motor rotation and the dough from the feed hopper drops down into the barrel for processing. The dough that has been processed is then removed through the mold.
\end{abstract}

Key words: bioconversion, maggot, pellet 


\section{PENDAHULUAN}

Belakangan ini cara memproses sampah berbasis biokonversi memang mulai banyak dikembangkan. Biokonversi adalah proses perombakan sampah organik menjadi sumber energi metan melalui proses fermentasi yang melibatkan organisme hidup (Newton, dkk., 2005). Dengan program biokonversi, kandungan nutrien yang ada pada sampah organik bisa dibentuk menjadi nutrien bentuk lain yaitu biomassa. Black Soldier Fly (Hermetia Illucens) adalah Lalat yang berasal dari Amerika dan selanjutnya tersebar ke wilayah subtropis dan tropis di dunia (Čičková, dkk., 2015).

Lalat Black Soldier Fly/lalat BSF saat ini banyak digunakan peternak untuk memangkas biaya pakan dengan memanfaatkan larva dari lalat tersebut atau biasa disebut sebagai maggot $B S F$. Lalat jenis ini berbeda dengan jenis lalat yang lain karena lalat ini bukan merupakan lalat hama dan tidak dijumpai pada pemukiman yang padat penduduk sehingga relatif aman jika dilihat dari segi kesehatan manusia (Li, dkk., 2011).

Melalui pengelolaan sampah organik yang dibantu dengan larva lalat $B S F$, kita dapat menyelesaikan dua masalah sekaligus yaitu mendapatkan nutrien dari maggot dan sampah organik pun bisa berkurang karena menjadi makanan dari maggot. Salah satu desa yang mulai membudidayakan dan memanfaatkan maggot lalat $B S F$ yaitu Desa Cluring, Kecamatan Cluring, Kabupaten Banyuwangi. Proses budidaya maggot BSF dilakukan di gudang Tempat Pengolahan Sampah Terpadu (TPST 3R).

Berdasarkan hasil survei yang dilakukan, mesin yang digunakan masih sederhana dengan menggunakan motor bensin untuk menggerakkan extruder untuk menekan adonan keluar dari cetakan. Proses tersebut menghasilkan pelet yang belum maksimal, salah satunya yaitu pelet yang keluar masih berbentuk panjang karena tidak dilengkapi dengan pemotong. Dari masalah tersebut, dapat disimpulkan bahwa dalam pembuatan pelet maggot diperlukan adanya peningkatan (upgrading) terhadap mesin yang digunakan dengan cara redesain mesin yang ada, agar memiliki kualitas yang lebih baik dari sebelumnya.

\section{TINJAUAN PUSTAKA}

\section{Landasan Teori Lalat BSF}

Lalat BSF/Black Soldier Fly (Hermetia illucens) ini tersebar hampir di seluruh dunia. Dalam siklus hidupnya lalat $B S F$ memiliki lima fase. Lima fase tersebut yaitu fase dewasa, fase telur, fase prepupa, dan fase pupa. Dari ke-lima fase tersebut, fase prepupa sering digunakan sebagai pakan ikan (Newton, dkk., 2005). Pada fase prepupa tersebut, kita lebih mengenalnya sebagai maggot $B S F$ yang dapat dilihat pada Gambar 1. Maggot BSF tersebut dapat memakan apa saja, seperti sisa makanan, sampah, makanan yang sudah terfermentasi, sayuran, buah-buahan, bahkan bangkai hewan.

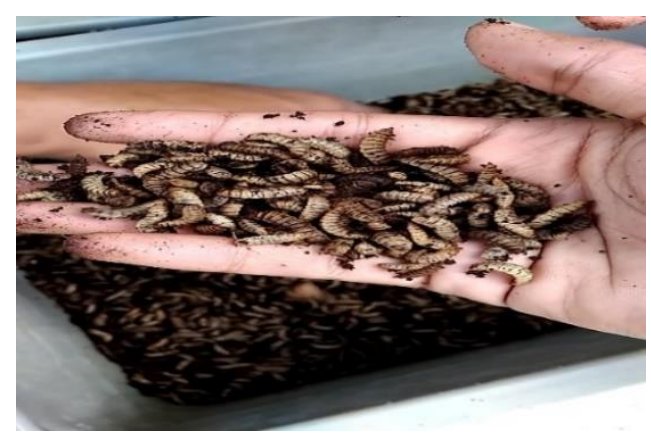

Gambar 1. Maggot $B S F$

\section{Pelet Maggot $B S F$}

Salah satu bentuk pemanfaatan maggot yaitu dibentuk menjadi pelet. Pelet merupakan bentuk pakan buatan yang dicetak bulat/batangan yang berasal dari campuran berbagai bahan sehingga membentuk sebuah adonan. Pelet juga dikenal sebagai bentuk massa dari bahan pakan yang dipadatkan sedemikian rupa dengan cara menekan melalui lubang cetakan secara mekanis (Zaenuri, dkk., 2014) sebagai contoh dapat dilihat pada

\section{Gambar 2.}

Selain sebagai pakan alternatif untuk ikan yang dapat diberikan dalam bentuk segar (fresh), maggot juga memiliki fungsi sebagai sumber protein alternatif pengganti tepung ikan. Hal tersebut karena maggot mengandung protein sekitar 32.31\%-60.20\% dan lemak yang tinggi sekitar $9.45 \%-13.30 \%$ tergantung umur dan kualitas substrat (Fahmi dan Subamia, 2007). Oleh karena itu, maggot dapat diolah menjadi bahan campuran pembuatan pelet untuk pakan ikan. 
Keuntungan pakan bentuk pelet adalah meningkatkan konsumsi dan efisiansi pakan, menurunkan jumlah pakan yang tercecer, memperpanjang waktu penyimpanan, menjamin keseimbangan zat-zat nutrisi pakan dan mecegah oksidasi vitamin.

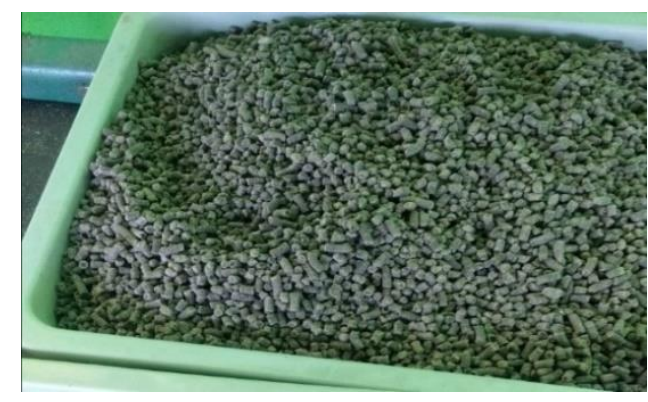

Gambar 2. Pelet Maggot BSF

\section{Mesin Yang Sudah Ada}

Mesin ini merupakan mesin yang ada di TPST 3R Desa Cluring, Kecamatan Cluring, Kabupaten Banyuwangi, tujuannya sebagai pembanding serta memperbaiki kekurangan dari alat/mesin yang akan dibuat. Dalam hal ini juga disertakan gambar mesin yang akan diredesain sesuai dengan kekurangannya seperti tampak pada Gambar 3.

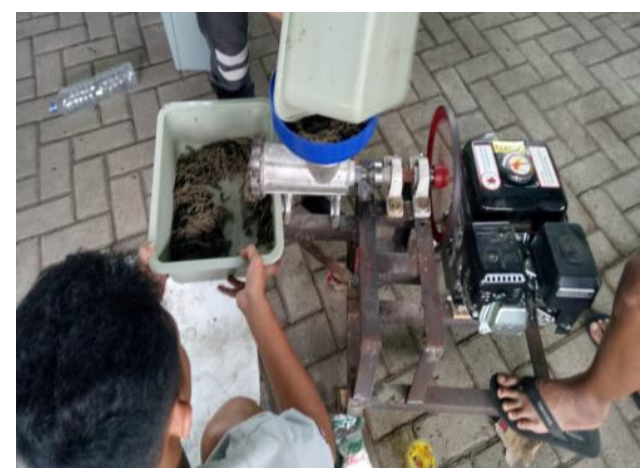

Gambar 3. Mesin Yang Sudah Ada

\section{Redesain Mesin Pencetak Pelet Maggot}

Redesain mesin pencetak pelet maggot ini memiliki bentuk silinder yang sama seperti mesin sebelumnya. Bagian dalamnya terdapat ulir pengepres/extruder pelet untuk mendorong bahan adonan ke ujung silinder sehingga menekan plat berlubang sebagai pencetak pelet yang dikehendaki.

\section{Perencanaan Komponen-Komponen Bagian}

\section{Dinamis Mesin}

Adapun beberapa komponen yang diperlukan pada bagian dinamis dapat dijelaskan sebagai berikut:

a. Motor Bakar

Motor bakar adalah salah satu jenis dari mesin kalor, yaitu mesin yang mengubah energi termal untuk melakukan kerja mekanik atau mengubah tenaga kimia bahan bakar menjadi tenaga mekanis (Agustianti, 2016). Energi tersebut diperoleh dari proses pembakaran yang dilaksanakan di dalam mesin.

Dalam pelaksanaannya, digunakan motor bakar jenis bensin yang sebagai motor penggerak extruder utama seperti tampak pada Gambar 4.

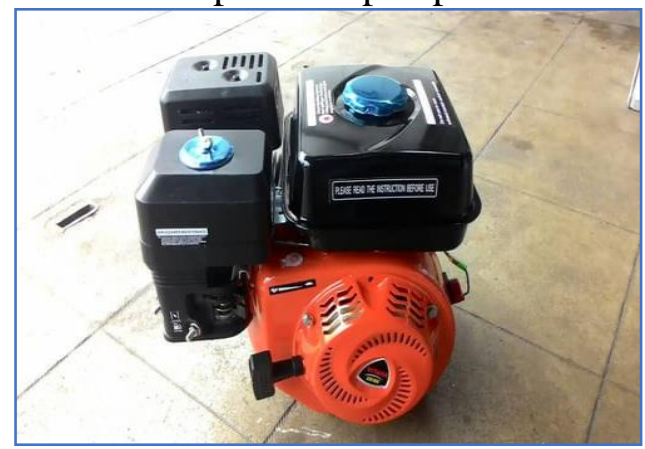

Gambar 4. Motor Bensin

Perhitungan daya yang direncanakan dihitung menurut persamaan- persamaan berikut:

1. Torsi yang diperlukan (Zainuri, 2008)

$$
T=F \cdot r
$$

Dimana gaya $(\mathrm{F})$

$$
\begin{aligned}
& F=\text { m.a ......... } \\
& \mathrm{T}=\text { torsi }(\mathrm{N} . \mathrm{mm}) \\
& \mathrm{F}=\text { gaya yang terjadi }(\mathrm{N}) \\
& \mathrm{r}=\text { jari-jari }(\mathrm{mm}) \\
& \mathrm{m}=\text { massa }(\mathrm{kg}) \\
& \mathrm{a}=\text { Percepatan }(\mathrm{m} / \mathrm{s} 2)
\end{aligned}
$$

2. Kerja yang dilakukan adalah daya $(\mathrm{P})$ (Zainuri, 2008)

$$
\begin{aligned}
& P= T .2 \pi n \\
& \text { Keterangan }: \\
& \mathrm{T}=\text { torsi }(\mathrm{N} . \mathrm{mm}) \\
& \mathrm{P}=\text { daya }(\text { watt }, \mathrm{kW}) \\
& \mathrm{F}=\text { gaya yang terjadi }(\mathrm{N}) \\
& \mathrm{r}=\text { jari-jari }(\mathrm{mm}) \\
& \mathrm{n}=\text { putaran per menit }(\mathrm{rpm})
\end{aligned}
$$


3. Untuk menjaga keamanan maka daya dikalikan faktor koreksi $\left(f_{c}\right)$ sehingga didapat daya rencana (Sularso dan Suga, 2004).

$$
p_{d}=f_{c} \times p \text {. }
$$

Keterangan :

$p_{d}=$ daya rencana $(\mathrm{kw})$

$f_{c}=$ faktor koreksi daya yang ditransmisikan

$p$ = daya nominal input poros $(\mathrm{kw})$

\section{b. Sabuk - V}

Sabuk - V adalah penghubung antara penggerak dan yang digerakkan dengan menggunakan tali yang terbuat dari karet. Keunggulan transmisi sabuk- $v$ adalah menghasilkan transmisi daya yang besar dan tenaga relatif rendah. Sabuk-v terbuat dari karet dan mempunyai bentuk trapesium, inti sabuk terbuat dari tenunan tetoran yang dipergunakan untuk membawa tarikan yang besar.

Sabuk-v dibelitkan pada pulley dan mengalami lengkungan sehingga lebar bagian dalamnya akan bertambah besar dan gaya gesekan akan bertambah karena mempengaruhi bentuk baji (Sularso dan Suga, 2004).

\section{c. Pulley}

Pulley adalah elemen yang fungsinya meneruskan daya dari sabuk-v ke poros seperti terlihat pada Gambar 7. Ukuran pulley (drive and driven) yang dipakai disesuaikan dengan kebutuhan kecepatan, sehingga keuntungan jika menggunakan pulley:

1. Tidak menimbulkan suara yang bising dan lebih tenang.

2. Kecepatan putaran dapat direduksi dengan menggunakan perbandingan ukuran pulley (drive and driven).

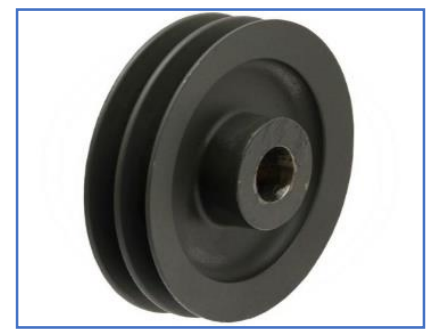

Gambar 7. Pulley

$V$-Belt

1. Perbandingan reduksi

$i=\frac{n 2}{n 1}$.

Keterangan : $i=$ reduksi

$n_{1}=$ putaran pada pulley penggerak

$n_{2}=$ putaran pada pulley yang digerakan (rpm)

2. Diameter lingkaran jarak bagi pulley penggerak (dp)

$D p=d p x i$

Keterangan :

$d p=$ diameter jarak bagi pulley penggerak $(\mathrm{mm})$

$D p=$ diameter jarak bagi pulley yang digerakan $(\mathrm{mm})$

$i=$ perbandingan putaran

3. Diameter luar pulley

a. Diameter pulley penggerak

$d k=d p+2 k$.

Keterangan:

$d k=$ diameter luar pulley kecil (mm)

$d p=$ diameter jarak bagi pulley kecil (mm)

$k=$ konstan

b. Diameter luar pulley yang digerakan

$D k=D p+2 k$

Keterangan:

$D k=$ diameter luar pulley besar $(\mathrm{mm})$

$D p=$ diameter jarak bagi pulley besar (mm)

$k$ = konstan

4. Kecepatan linier sabuk V

$V=\frac{d p \cdot n 1}{60 \times 1000}$

Keterangan:

$V=$ kecepatan linier sabuk $(\mathrm{m} / \mathrm{s})$

$d p=$ diameter pulley penggerak $(\mathrm{mm})$

$n 1=$ putaran pulley penggerak $(\mathrm{rpm})$

5. Panjang keliling sabuk $\mathrm{V}$

$L=2 C+1.57(D+d)+\frac{(D-d)^{2}}{4 C}$

Keterangan:

$D=$ diameter pulley yang digerakan $(\mathrm{mm})$

$d=$ diameter pulley penggerak $(\mathrm{mm})$

$C=$ jarak sumbu poros (mm)

6. Sudut kontak antara pulley dan sabuk

Sudut kontak $(\theta)$ dari sabuk pada alur penggerak harus diusahakan sebesar mungkin 
untuk memperbesar panjang kontak antara sabuk dan pulley. Gaya gesekan berkurang dengan mengecilkannya $(\theta)$ sehingga menimbulkan slip antara sabuk dan pulley.

Jika jarak poros adalah pendek sedangkan reduksinya besar, maka sudut kontak pada pulley kecil (pulley penggerak) akan menjadi kecil. Adapun rumus dari sudut kontak:

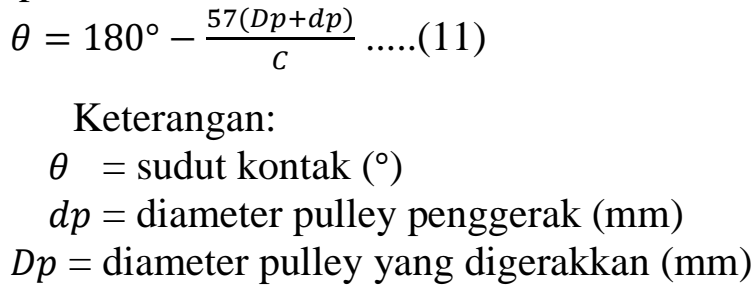

\section{Gaya tarik efektif pada pulley}

Jarak yang jauh antara dua buah poros sering tidak memungkinkan transmisi langsung dengan roda gigi. Dalam hal ini, transmisi daya dan putaran dilakukan melalui sabuk dan pulley.

Keuntungan penggunaan sistem transmisi sabuk adalah mampu menerima putaran cukup tinggi dan beban cukup besar sedangkan kerugiannya adalah suhu kerja agak terbatas sampai 80 derajat dan mudah slip. Adapun rumus dari gaya tarik efektif pada pulley:

$F e=\frac{\text { pox102 }}{V}$

Keterangan :

Po = daya yang ditransmisikan oleh sabuk (kw)

$\mathrm{V}=$ kecepatan linier sabuk $(\mathrm{m} / \mathrm{s})$

\section{d. Poros}

Poros merupakan salah satu bagian yang terpenting dari setiap mesin. Hampir semua mesin meneruskan tenaga bersamasama dengan putaran. Peran utama transmisi ini dipegang oleh poros (Sularso dan Suga, 2004).

Poros berfungsi untuk menyalurkan daya atau tenaga melalui putaran yang telah dipasang dengan kopling, roda gigi, puli, sabuk, atau sproket rantai dan lain-lain.

Model poros yang digunakan pada mesin pencetak pelet maggot merupakan poros spindel yang dapat dilihat pada pada

\section{Gambar 8.}

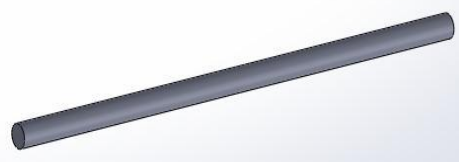

Gambar 8. Poros Spindel

Untuk merencanakan dan menghitung kontruksi sebuah poros, dapat dilakukan dengan menggunakan rumus berikut:

1. Menghitung momen puntir (Sularso dan Suga, 2004)

$$
T=9,74 \times 10^{5} \frac{P d}{n 2}
$$

Keterangan:

$\mathrm{T}=$ momen puntir (N.mm)

$\mathrm{n} 2=$ putaran poros $(\mathrm{rpm})$

$\mathrm{Pd}=$ daya rencana $(\mathrm{kw})$

2. Menentukan Tegangan-Regangan Tarik

Menurut Zainuri (2008), deformasi bahan yang disebabkan oleh beban tarik adalah dasar pengujian dan kajian mengenai kekuatan bahan. Hal ini disebabkan oleh beberapa alasan, yaitu:

a. Mudah dilakukan

b. Menghasilkan tegangan merata pada penampang

c. Kebanyakan bahan lebih mudah dilakukan uji tarik daripada uji tekan, misalnya, sehingga dalam pengujian bahan teknik, kekuatan paling sering dinyatakan dengan uji tarik.

Berikut rumus untuk menetukan tegangan-regangan tarik (Gere dan Timoshenko, 2000). $\sigma=\mathrm{P} / \mathrm{A}$

\section{Keterangan :}

$\sigma=$ Tegangan tarik $\left(\mathrm{N} / \mathrm{mm}^{2}\right)$

$\mathrm{P}$ = Gaya aksial $(\mathrm{N})$

A $=$ Luas penampang $(\mathrm{mm} 2)$

$\varepsilon=\frac{\delta}{L}$

Keterangan :

$\varepsilon=$ Regangan $(\%)$

$\delta=$ Panjang akhir (mm) 

$\mathrm{L}=$ Panjang awal $(\mathrm{mm})$

Jika gaya persatuan luasan disebut tegangamm dan pertambahan panjang disebut regangan maka hubungan ini dinyatakan dengan grafik tegangan dan regangan (stress-strain graph) (Zainuri, 2008). Grafik/Diagram Tegangan-

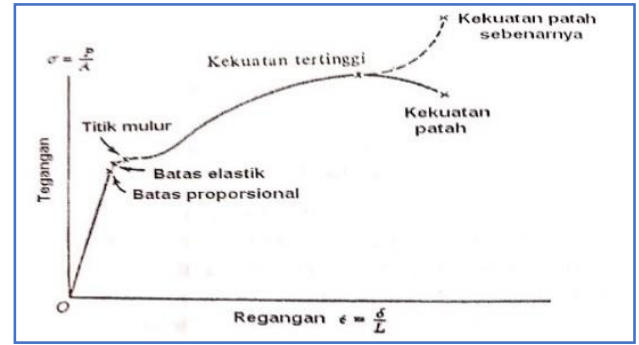

Regangan dapat dilihat pada Gambar 9.

Gambar 9. Diagram Tegangan-Regangan

3. Tegangan geser yang diijinkan (Sularso dan Suga, 2004)

$\tau_{a}=\frac{\sigma \mathrm{B}}{\mathrm{Sf} 1 \times \mathrm{Sf} 2}$.

Keterangan :

$\sigma \mathrm{B}=$ Kekuatan tarik $(\mathrm{N} / \mathrm{mm} 2)$

$\tau_{a}=$ Tegangan geser yang dijinkan

$(\mathrm{N} / \mathrm{mm} 2)$

$S f 1=$ Faktor kekekuatan 6

$S f 2=$ Faktor kekerasan 1,3-3,0

4. Menentukan diameter poros untuk beban puntir (Sularso dan Suga, 2004)

$d_{s}=[(5,1 / \tau \alpha) K t \times C b \times T]^{\frac{1}{3}}$.

Keterangan :

$\mathrm{ds}=$ diameter poros $(\mathrm{mm})$

$\tau a=$ tegangan geser yang diizinkan

$\left(\mathrm{N} / \mathrm{mm}^{2}\right)$

$\mathrm{Kt}=$ faktor koreksi momen puntir

$\mathrm{Cb}=$ faktor lenturan

$\mathrm{T}=$ momen puntir (N.mm)
Faktor ini dinyatakan dengan $K t$, dipilih sebesar 1,0 jika beban dikenakan secara halus, 1,0-1,5 jika terjadi sedikit kejutan atau tumbukan, dan 1,5-3,0 jika beban dikenakan dengan kejutan atau tumbukan besar (Sularso dan Suga, 2004).

e. Bantalan

Bantalan adalah elemen mesin yang menumpu poros berbeban. Bantalan harus cukup kokoh untuk memungkinkan poros serta elemen mesin lainya bekerja dengan baik, jika bantalan tidak berfungsi dengan baik maka seluruh sistem akan menurun atau tidak dapat bekerja secara semestinya (Sularso dan Suga, 2004). Bantalan dapat dilihat pada Gambar 10.

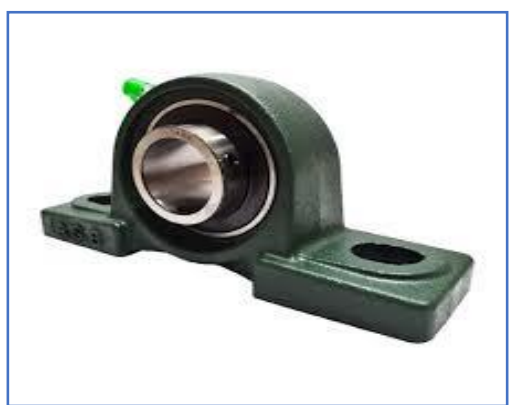

Gambar 10. Bantalan

Bantalan yang akan digunakan pada redesain mesin pencetak pelet maggot ada 2 macam yaitu jenis bantalan gelinding yang membawa beban aksial dan juga jenis bantalan gelinding yang membawa beban radial. Perencanaan dan perhitungan bantalan dapat diketahui dengan persamaan berikut :

1. Perhitungan beban ekivalen dinamis. Beban yang besarnya sedemikian rupa sehingga memberikan umur yang sama dengan umur yang diberikan oleh beban dan kondisi putaran sebenarnya (Sularso dan Suga, 2004).

$\mathrm{Pr}=$ X.V.Fr. + Y.F $\alpha$

Keterangan :

$\operatorname{Pr}=$ Beban ekivalen dinamis $(\mathrm{kg})$

$\mathrm{X}=$ Faktor beban radial

$\mathrm{Fr}=$ Beban radial $(\mathrm{kg})$

$\mathrm{Y}=$ Faktor beban aksial

$\mathrm{F} \alpha=$ Beban aksial $(\mathrm{kg})$

2. Faktor kecepatan putaran bantalan (Sularso dan Suga, 2004) 
$f n=\left(\frac{33,3}{n}\right)^{\frac{1}{3}}$

Keterangan :

$f \mathrm{n}=$ Faktor kecepatan putaran bantalan

$\mathrm{n}=$ Jumlah putaran (rpm)

3. Faktor umur bantalan (Sularso dan Suga, 2004)

$f_{h=f n \frac{c}{p}}$

Keterangan :

$\mathrm{fh}=$ Faktor umur

$\mathrm{C}=$ Beban normal spesifikasi $(\mathrm{kg})$

$\mathrm{P}=$ Beban ekivalen dinamis $(\mathrm{kg})$

$\mathrm{fn}=$ Faktor kecepatan putaran bantalan

4. Umur nominal bantalan (Sularso dan Suga, 2004)

$L h=500 f_{h}^{3}$

Keterangan :

$\mathrm{Lh}=$ Faktor nominal (jam)

$\mathrm{fh}=$ Faktor umur

\section{f. Extruder}

Extruder/screw press adalah alat yang digunakan untuk menekan adonan pelet sehingga bergerak menuju ujung barell dan keluar melalui piringan pembentuk pelet yang sudah terdapat lubang dengan diameter seragam.

Gaya sentrifugal yang terjadi pada extruder menyebabkan berpindahnya adonan pelet karena adanya putaran dari screw press secara rotasi pada barell. Hal ini pula yang menyebabkan adonan mempunyai tekstur padat ketika proses penggilingan menjadi pelet. Screw press dapat dilihat pada Gambar 11.

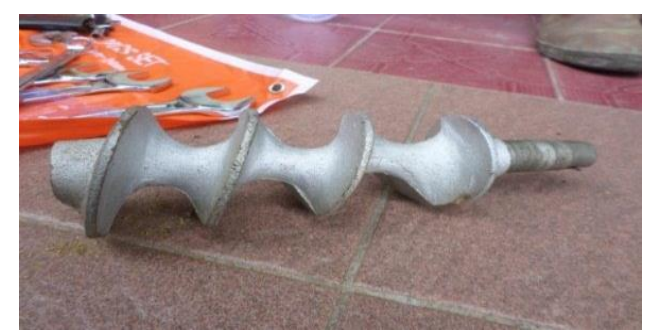

Gambar 11. Extruder/Screw Press
Pisau pemotong merupakan komponen penting pada mesin pencetak pelet. Panjang pelet yang dihasilkan tergantung pada pengaturan jarak antara pisau/jumlah mata pisau yang digunakan seperti yang tampak pada Gambar 12. Selain itu, putaran motor juga ikut mempengaruhi terhadap ukuran panjang pelet yang dihasilkan.

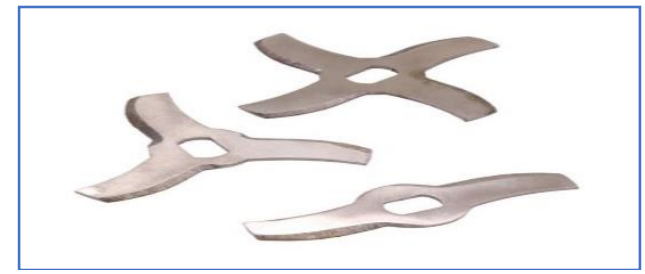

Gambar 12. Pisau Pemotong

Menurut Nainggolan dan Herman (2017), untuk menghitung

kemampuan pisau pemotong dapat digunakan persamaan :

$$
\begin{aligned}
& \text { Cs }=\frac{\pi \cdot d \cdot n}{1000} \\
& \text { Keterangan : } \\
& \text { Cs }=\text { Kecepatan potong }(\mathrm{m} / \mathrm{s}) \\
& \mathrm{d}=\text { diameter pisau }(\mathrm{mm}) \\
& \mathrm{n}=\text { putaran motor }(\mathrm{rpm})
\end{aligned}
$$

\section{METODOLOGI}

\section{Desain Mesin Pencetak Pelet Maggot}

Mesin pencetak pelet maggot adalah salah satu mesin yang berfungsi untuk memproduksi dan mencetak pelet atau pakan ternak ikan dengan kapasitas produksi tertentu. Mesin cetak pelet sangat efektif untuk menghasilkan pakan dalam bentuk simetris.

Mesin ini menggunakan panas yang dihasilkan dari gesekan antara bahan dan extruder dalam proses pengeringannya. Efek panas yang ditimbulkan dari proses tersebut membuat pelet dapat mengembang. Pelet yang keluar dari cetakan akan dipotong oleh pisau yang kemudian keluar dari cetakan tersebut dalam bentuk pelet siap pakai melalui hopper out. Desain mesin pencetak pelet maggot dapat dilihat pada Gambar 13.

\section{g. Pisau Pemotong}




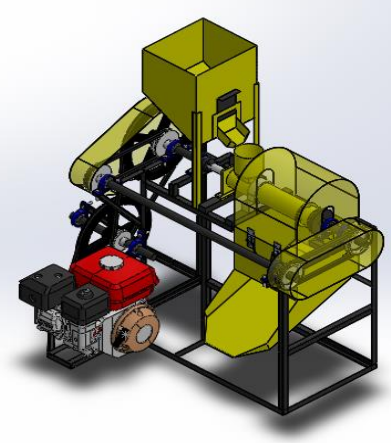

Gambar 13. Mesin Pencetak Pelet Maggot

Bagian-bagian mesin pencetak pelet :

1. Motor Bensin

2. Hopper

3. Barrel

4. Extruder

5. Rangka

6. Poros dan Puli

\section{Perencanaan dan Perancangan}

Dalam tahapan ini, perencanaan adalah kegiatan awal yang digunakan untuk merancang suatu mesin. Perencanaan dan perancangan mesin yang akan dilakukan adalah sebagai berikut:

1. Tahap Desain

Desain mesin adalah langkah awal dalam merancang suatu mesin. Pembuatan desain dilakukan dengan menggunakan aplikasi solidworks.

2. Persiapan Alat dan Bahan

Setelah desain gambar dan perhitungan telah rencanakan, langkah selanjutnya adalah persiapan alat dan bahan.

3. Pembuatan Alat

Bahan yang telah dipersiapkan akan dibuat menjadi alat sesuai desain yang telah dibuat sebelumnya dengan menggunakan mesin perkakas. Pembuatan alat tersebut disesuaikan dengan ukuran gambar dengan berbagai penyesuaian.

\section{Pengujian}

Jika perancangan mesin telah selesai, langkah kerja yang selanjutnya adalah menguji mesin tersebut agar dapat bekerja secara optimal. Pengujian ini juga dilakukan untuk mencari kekurangan pada bagian-bagian mesin yang selanjutkan akan disempurnakan.

\section{Perbaikan}

Tahapan ini dilakukan untuk menyempurnakan perancangan dan mekanisme mesin. Hal ini dilakukan untuk menghindari tejadinya masalah atau kerusakan pada mesin agar mesin dapat menghasilkan produk yang sesuai keinginan.

\section{HASIL DAN PEMBAHASAN Motor}

Pada perencanaan motor, ada beberapa perhitungan yang digunakan sebagai berikut:

1. Menghitung percepatan mengalirkan adonan

Berat beban adonan yang direncanakan yang mampu ditampung oleh hopper atas yaitu sebesar 5 kg. Sedangkan untuk a (percepatan mengalirkan adonan) diketahui dari perhitungan berikut.

$$
\begin{aligned}
& \mathrm{a}=\frac{V}{t} \\
& \mathrm{~V}=\mathrm{s} / \mathrm{t} \\
& \mathrm{s}=300 \mathrm{~mm}=0,3 \mathrm{~m} \text { (panjang extruder } / \text { screw } \\
& \quad \text { press yang direncanakan) } \\
& \mathrm{t}=0,5 \mathrm{~s} \text { (asumsi waktu yang digunakan) } \\
& \mathrm{V}=0,3 / 0,5 \\
& =0,6 \mathrm{~m} / \mathrm{s}
\end{aligned}
$$

Sehingga percepatan yang terjadi yaitu:

$$
\begin{aligned}
& \mathrm{a}=\frac{V}{t} \\
& \mathrm{~V}=0,6 \mathrm{~m} / \mathrm{s} \\
& t=0,5 \\
& \mathrm{a}=\frac{0,6}{0,5} \\
& =1,2 \mathrm{~m} / \mathrm{s}^{2}
\end{aligned}
$$

2. Menghitung gaya yang terjadi

$$
\begin{aligned}
& \mathrm{F}=\mathrm{m} . \mathrm{a} \\
& \mathrm{m}=5 \mathrm{~kg} \\
& \mathrm{a}=1,2 \mathrm{~m} / \mathrm{s}^{2} \\
& \mathrm{~F}=5.1,2 \\
& =6 \mathrm{~N}
\end{aligned}
$$

3. Menghitung torsi yang terjadi

$$
\begin{aligned}
& \mathrm{T}=\mathrm{F} \cdot \mathrm{r} \\
& \mathrm{F}=6 \mathrm{~N} \\
& \mathrm{r}=25,5 \mathrm{~mm} \text { (setengah diameter mayor } \\
& \text { poros extruder yang direncanakan) } \\
& \mathrm{T}=6.25,5 \\
& \mathrm{~T}=153 \mathrm{~N} . \mathrm{mm}
\end{aligned}
$$

4. Menghitung daya yang terjadi 
Sebelum menghitung daya yang diinginkan, terlebih dahulu mengetahui daya motor yang terjadi dengan rumus berikut :

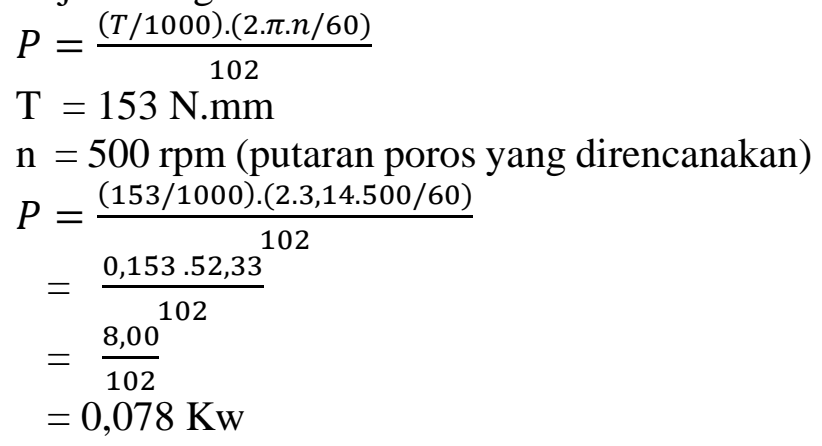

5. Menghitung daya rencana

$$
\begin{aligned}
& P d=f c \times \mathrm{P} \\
& f c=1,2(\text { nilai faktor koreksi) } \\
& \mathrm{P}=0,078 \mathrm{Kw} . \\
& \begin{array}{c}
P d=1,2.0,078 \\
=0,09 \mathrm{Kw} \\
\quad=0,12 \mathrm{HP}
\end{array}
\end{aligned}
$$

Dengan demikian, motor yang akan digunakan yaitu motor dengan daya 0,12 HP. Mengantisipasi kemungkinan terjadi kelebihan beban, maka daya motor yang digunakan dapat ditingkatkan menjadi 0,50 HP maupun di atasnya.

Pada redesain mesin pencetak pelet maggot ini, motor yang digunakan yaitu motor bensin Vitara CX 160. Diketahui motor memiliki daya 5,5 PS/HP dan putaran maksimal motor sebesar 3600 rpm atau bisa diasumsikan bukaan gas penuh sehingga dapat dikatakan motor yang digunakan aman. Karena untuk sekali proses pembuatan pelet maggot sesuai dengan data di atas, hanya memerlukan daya motor $0,12 \mathrm{HP}$.

\section{Sabuk dan Puli}

Pada perencanaan v-belt dan pulley utama, terdapat beberapa perhitungan yang digunakan untuk menentukannya dengan diketahui data sebagai berikut:

$\mathrm{Pd}=5,5 \mathrm{HP}(4,103 \mathrm{Kw})$

$\mathrm{n}=3600 \mathrm{rpm}$ (putaran maksimal motor)

$\mathrm{n} 1=1600 \mathrm{rpm}$ (putaran motor yang digunakan sebagai acuan)

$\mathrm{n} 2=500 \mathrm{rpm}$ (putaran yang direncanakan)

Dari data di atas, dapat digolongkan sabuk yang digunakan adalah sabuk tipe A dengan melihat daya rencana $(\mathrm{Pd})$ dan putaran motor/puli kecil (n). Putaran motor/puli kecil (n) yang digunakan yaitu $\mathrm{n} 1$ (1600 rpm).

1. Menentukan perbandingan reduksi

$$
\begin{aligned}
i= & \frac{n 1}{n 2} \\
\mathrm{n} 1 & =1600 \mathrm{rpm} \\
\mathrm{n} 2 & =500 \mathrm{rpm} \\
\mathrm{i} & =\frac{1600}{500} \\
& =3,2
\end{aligned}
$$

Hasil perbandingan reduksi ini yaitu 1 :

3,2 dengan putaran motor yaitu $1600 \mathrm{rpm}$ direduksi menjadi 500 rpm. Hasil tersebut akan digunakan dalam menentukan diameter nominal pada puli yang digerakan.

2. Menentukan diameter puli yang digerakan (driven)

$\mathrm{Dp}=\mathrm{dp} \times \mathrm{i}$

$\mathrm{dp}=95 \mathrm{~mm}$ (diameter min. yang dianjurkan)

$$
\begin{aligned}
\mathrm{i} & =3,2 \\
\mathrm{Dp} & =95 \times 3,2 \\
& =304 \mathrm{~mm}
\end{aligned}
$$

$304 \mathrm{~mm}$ merupakan nilai yang didapatkan dalam perhitungan.

3. Menentukan diameter luar puli yang digerakan (driven)

$$
\begin{aligned}
\mathrm{Dk} & =\mathrm{Dp}+2 \mathrm{k} \\
\mathrm{Dp} & =304 \\
\mathrm{k} & =4,5 \\
\mathrm{Dk} & =\mathrm{Dp}+2 \mathrm{k} \\
& =304+2.4,5 \\
& =304+9
\end{aligned}
$$

$\mathrm{Dk}=313 \mathrm{~mm}$

Hasil perhitungan tersebut digunakan sebagai acuan untuk memilih ukuran puli yang ada di pasaran. Menggunakan ukuran terdekat dari perhitungan dan didapatkan ukuran yang ada di pasaran yaitu sebesar 304,8 mm /12 inch.

4. Menentukan diameter luar puli penggerak $\mathrm{dk}=\mathrm{dp}+2 . \mathrm{k}$ $\mathrm{dp}=95$

$$
\begin{aligned}
\mathrm{k} & =4, \\
\mathrm{dk} & =95+2.4,5 \\
=104 \mathrm{~mm} &
\end{aligned}
$$

Hasil perhitungan tersebut digunakan sebagai acuan untuk memilih ukuran puli yang ada di 
pasaran. Menggunakan ukuran terdekat dari perhitungan dan didapatkan ukuran yang ada di pasaran yaitu sebesar 101,6 mm /4 inch.

5. Menentukan jarak antar poros

$$
\begin{aligned}
\mathrm{C} & =2 \times \mathrm{Dp} \\
& =2 \times 304 \\
& =608 \mathrm{~mm}
\end{aligned}
$$

Hasil perhitungan tersebut merupakan jarak minimal dalam menentukan panjang sabuk.

6. Menentukan panjang keliling sabuk

$$
\begin{aligned}
L & =2 C+\frac{\pi}{2}\left(d_{p}+D_{p}\right)+\frac{1}{4 C}\left(D_{p}-d_{p}\right)^{2} \\
\mathrm{C} & =608 \mathrm{~mm} \\
\mathrm{dp} & =95 \mathrm{~mm} \\
\mathrm{Dp} & =304 \mathrm{~mm} \\
\mathrm{~L} & =2.608+\frac{3,14}{2}(95+304)+\frac{1}{4.608}(304-95)^{2} \\
& =1216+1,57(399)+\frac{1}{4.608}(209)^{2} \\
& =1216+1,57(399)+\frac{1}{2432}(43681) \\
& =1216+626,43+0,00041(43681) \\
& =1216+626,43+17,96 \\
& =1860,39 \mathrm{~mm}
\end{aligned}
$$

Hasil perhitungan tersebut kemudian disesuaikan dengan ukuran panjang sabuk-V standar dan didapatkan ukuran panjang sabuk yaitu $1880 \mathrm{~mm}$ / 74 inch.

Berdasarkan data di atas, digunakan sabuk-v dengan merk Bando tipe A-73 dimana dalam katalog sabuk tersebut menjelaskan bahwa ukuran panjang bagian dalam (datum lenght) $=74,3$ inch .

7. Menentukan jarak sumbu poros

$$
\mathrm{b}=2 \mathrm{~L}-3,14(\mathrm{Dp}+\mathrm{dp})
$$

Dalam menentukan jarak sumbu poros, nilai $\mathrm{L}$ pada keliling sabuk yang digunakan yaitu nilai yang telah disesuaikan dengan referensi.

Jadi, perhitungan jarak sumbu poros sebagai berikut:

$$
\begin{aligned}
\mathrm{L} & =1854 \mathrm{~mm} \\
\mathrm{Dp} & =304 \mathrm{~mm} \\
\mathrm{dp} & =95 \mathrm{~mm} \\
\mathrm{~b} & =2.1854-3,14(304+95) \\
& =3708-3,14 .(399) \\
& =3708-1252,86 \\
& =2455,14 \mathrm{~mm}
\end{aligned}
$$

Untuk dapat mendapatkan nilai sebenarnya dari menentukan jarak sumbu poros yaitu menggunakan persamaan rumus berikut:

$$
\begin{aligned}
& C=\frac{b+\sqrt{b^{2}-8(D p-d p)^{2}}}{8} \\
& \mathrm{~b}=2455,14 \mathrm{~mm} \\
& \mathrm{Dp}=304 \mathrm{~mm} \\
& \mathrm{dp}=95 \mathrm{~mm} \\
& \mathrm{C} \\
& =\frac{2455,14+\sqrt{2455,14^{2}-8(304-95)^{2}}}{8} \\
& =\frac{2455,14+\sqrt{2455,14^{2}-8(209)^{2}}}{8} \\
& =\frac{2455,14+\sqrt{6027712,4196-8(43681)}}{8} \\
& =\frac{2455,14+\sqrt{6027712,4196-349448}}{8} \\
& =\frac{2455,14+\sqrt{5678264,4196}}{8} \\
& =\frac{2455,14+2382,91}{8} \\
& =\frac{4838,05}{8} \\
& =604,75 \mathrm{~mm}
\end{aligned}
$$

Dari hasil tersebut dapat dibandingkan dengan perhitungan jarak antar poros sebelumnya yaitu mendapatkan nilai $608 \mathrm{~mm}$ dan jarak sumbu poros sebenarnya $604,75 \mathrm{~mm}$.

8. Menentukan kecepatan linier sabuk

$$
\begin{gathered}
V=\frac{\pi \cdot d_{\mathrm{p}} \cdot \mathrm{n}_{1}}{60.1000} \\
\mathrm{dp}=95 \mathrm{~mm} \\
\mathrm{n} 1=1600 \mathrm{rpm} \\
\mathrm{V}=\frac{3,14.95 .1600}{60.1000} \\
=\frac{477280}{60000} \\
=7,95 \mathrm{~m} / \mathrm{s}
\end{gathered}
$$

Hasil perhitungan tersebut merupakan kecepatan sabuk bergerak berputar dari puli kecil ke puli besar.

9. Menentukan sudut kontak

Besar kecilnya sudut kontak akan mempengaruhi kinerja sabuk terhadap kejadian slip.

$$
\begin{gathered}
\theta=180^{\circ}-\frac{57(D p-d p)}{C} \\
\mathrm{Dp}=304 \mathrm{~mm} \\
\mathrm{dp}=95 \mathrm{~mm} \\
\mathrm{C}=604,75 \mathrm{~mm} \\
\theta=180^{\circ}-\frac{57(304-95)}{604,75}
\end{gathered}
$$




$$
\begin{aligned}
& =180^{\circ}-\frac{57(209)}{604,75} \\
& =180^{\circ}-\frac{11913}{604,75} \\
& =180^{\circ}-19,69 \\
& =160,31^{\circ}
\end{aligned}
$$

10. Menentukan gaya tarik efektif sabuk terhadap kemiringan sabuk

$$
\begin{aligned}
f_{\mathrm{e}} & =\frac{\mathrm{P}_{\mathrm{o}} \times 102}{V} \\
\mathrm{P}_{\mathrm{o}} & =\quad \text { Kapasitas daya yang } \\
& \text { ditransmisikan } \\
\mathrm{V}= & \text { Kecepatan liniear sabuk } \\
\mathrm{Po} & =1,43+0,20 \\
& =1,63 \\
\mathrm{~V} & =7,95 \mathrm{~m} / \mathrm{s} \\
f_{\mathrm{e}}= & \frac{1,63 \times 102}{7,95} \\
& =\frac{166,26}{7,95} \\
& =20,91 \mathrm{Kg} \\
& =21 \mathrm{Kg}
\end{aligned}
$$

nilai gaya tarik efektif sabuk ini nantinya akan digunakan untuk menentukan perhitungan potongan pada poros dan momen terbesar.

\section{Poros Extruder (Screw Press)}

Dalam pemilihan extruder menggunakan perencanaan dan perhitungan dengan ukuran yang dapat dilihat pada Gambar 14. Hal tersebut yang nantinya akan digunakan sebagai acuan pembelian extruder yang tersedia di pasaran atau perencanaan pembuatan extruder.

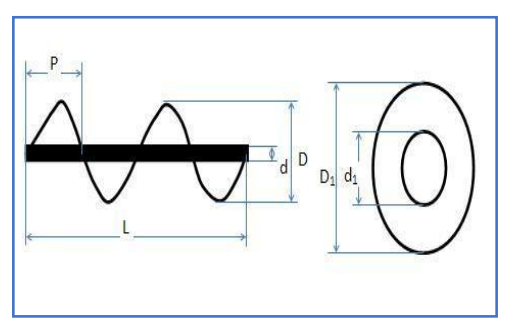

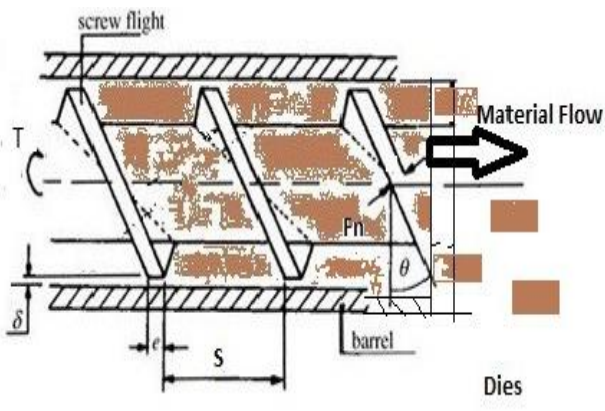

Gambar 14. Bagian Extruder

Keterangan :

Diameter mayor screw press $(\mathrm{D})=51 \mathrm{~mm}$

Panjang screw press $(\mathrm{L})=300 \mathrm{~mm}$

Pith screw pers $(\mathrm{P})=45 \mathrm{~mm}, 29 \mathrm{~mm}, 18 \mathrm{~mm}$

Diameter minor screw press $(\mathrm{d})=42 \mathrm{~mm}$

Sudut kemiringan screw $(\alpha)=10^{\circ}$

Sudut kemiringan screw terhadap sumbu $(\theta)=$ $100^{\circ}$

Diameter luar barrel $=72 \mathrm{~mm}$

Diameter dalam barrel $=60 \mathrm{~mm}$

1. Menentukan gaya momen/torsi untuk mengeluarkan adonan

Torsi yang digunakan untuk mengeluarkan adonan diambil dari hasil perhitungan momen puntir terbesar pada poros yaitu sebesar 78327,911 N.mm. Selain itu, untuk menentukan gaya momen/torsi dapat diketahui dari hasil analisa dengan memutar extruder dengan bantuan neraca pegas seperti tampak pada Gambar 15.

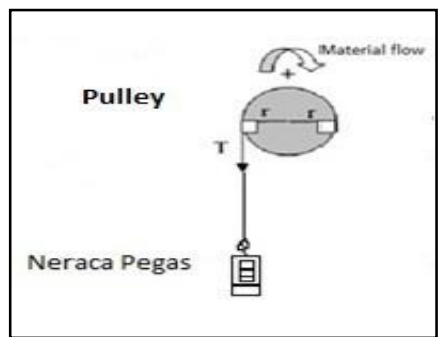

Gambar 15. Pengukuran Torsi

2. Menentukan gaya yang timbul ke arah tangensial $(\mathrm{Ft})$

Kesamaan gaya tangensial adalah searah dengan gaya memutar extruder untuk mengalirkan adonan. Dimana :

a. Gaya arah tangensial $=F n$. $\operatorname{Sin} \alpha$

b. Gaya arah tangensial $=$ Fn. f. $\cos \alpha$

Sehingga gaya torsi yang terjadi : 
a. $\mathrm{T}=$ Ft. $\mathrm{r}$

b. $T=$ Fn. $\left(\operatorname{Sin} \alpha+f^{\prime} \cdot \cos \alpha\right) \cdot R$

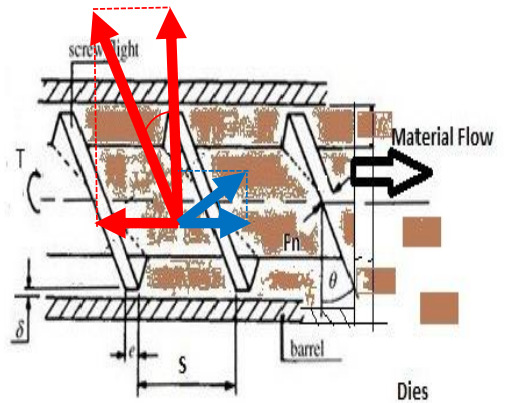

Gambar 16. Sudut yang terbentuk pada Extruder

$$
\begin{aligned}
& A=F a \cdot F \cdot \operatorname{Sin} \alpha \\
& B=F a \cdot F \\
& C=\text { Fa. F. Cos } \alpha \\
& D=\text { Fn. Sin } \alpha \\
& E=\text { Fn. Cos } \alpha
\end{aligned}
$$

Harga koefisien gesek untuk material sejenis barley (semacam gandum, beras) yang mempunyai kelembaban dan terjadi pada massa jenis $840 \mathrm{~kg} / \mathrm{m} 3$, maka material mempunyai harga koefisien gesek sebesar 0,4314 (Aria, dkk., 2003).

Perhitungan Torsi yang dibutuhkan poros screw didapat dari gaya yang terjadi pada arah tangensial, seperti berikut :

$$
\begin{aligned}
& \mathrm{T}=\mathrm{Ft} . \mathrm{r} \\
& =\text { Fn. }\left(\operatorname{Sin} \alpha+\mathrm{f}^{\prime} \cdot \cos \alpha\right) \cdot \mathrm{r} \\
& \mathrm{T}=78327,911 \text { N.mm (didapatkan dari } \\
& \text { perhitungan torsi poros dengan } \\
& \text { daya motor bensin 5,5 HP) } \\
& \mathrm{r}=\mathrm{D} / 2 \\
& =51 / 2 \\
& =25,5 \mathrm{~mm} \\
& \alpha=10^{\circ} \\
& \mathrm{f}^{\prime}=0,4314 \text { (koefisien gesek) } \\
& \mathrm{T}=\mathrm{Fn} .\left(\operatorname{Sin} \alpha+\mathrm{f}^{\prime} \cdot \cos \alpha\right) \cdot \mathrm{r} \\
& 78327,911 \text { N.mm }=\text { Fn. }(\text { Sin } 10+0,4314 \cdot \text { Cos } \\
& \text { 10). } 25,5 \mathrm{~mm} \\
& 78327,911 \mathrm{~N} \cdot \mathrm{mm}=\text { Fn. }(0,59) \cdot 25,5 \mathrm{~mm} \\
& 78327,911 \text { N.mm }=\text { Fn. } 15,261 \mathrm{~mm} \\
& \mathrm{Fn}=78327,911 \text { N.mm / 15,261 mm } \\
& \mathrm{Fn}=5132,351 \mathrm{~N}
\end{aligned}
$$

Sehingga gaya arah tangensial $(\mathrm{Ft})$ :

$$
\begin{aligned}
\mathrm{Ft} & =\mathrm{Fn} .\left(\operatorname{Sin} \alpha+\mathrm{f}^{\prime} \cdot \cos \alpha\right) \\
& =5132,351 \mathrm{~N}(\operatorname{Sin} 10+0,4314 \cdot \cos \\
& 10)
\end{aligned}
$$

$$
\begin{aligned}
& =5132,351 \mathrm{~N}(0,59) \\
\mathrm{Ft} & =3071,682 \mathrm{~N}
\end{aligned}
$$

3. Menentukan gaya yang timbul ke arah aksial (Fa)

a. Gaya arah aksial terhadap material $=$ Fn. $\mathrm{f}^{\prime}$. Sin $\alpha$

b. Gaya arah aksial terhadap gaya normal $=$ Fn. $\operatorname{Cos} \alpha$

Persamaan gaya aksial yang terjadi:

a. $\mathrm{Fa}=\mathrm{Fn} .\left(\operatorname{Cos} \alpha-\mathrm{f}^{\prime} . \operatorname{Sin} \alpha\right)$

Sehingga gaya arah aksial $(\mathrm{Fa})$ :

$$
\begin{aligned}
\mathrm{Fa} & =\text { Fn. }\left(\operatorname{Cos} \alpha-\mathrm{f}^{\prime} \cdot \operatorname{Sin} \alpha\right) \\
& =5132,351 \mathrm{~N} \cdot(\operatorname{Cos} 10- \\
& 10) \\
& =5132,351 \mathrm{~N} \cdot 0,90 \\
\mathrm{Fa} & =4669,90 \mathrm{~N}
\end{aligned}
$$$$
=5132,351 \mathrm{~N} .(\operatorname{Cos} 10-0,4314 . \mathrm{Sin}
$$

4. Torsi yang terjadi sebenarnya

Berdasarkan perhitungan tersebut, torsi yang terjadi sebenarnya dapat dicari dengan mengganti data yang telah digunakan sebelumnya pada rumus berikut.

$\mathrm{T}=\mathrm{F} . \mathrm{r}$

$\mathrm{Fa}=4669,90 \mathrm{~N}$ (F aksial ekstruder)

$\mathrm{r}=25,5 \mathrm{~mm}$ (setengah diameter mayor poros extruder yang direncanakan)

$\mathrm{T}=4669,90$ N. $25,5 \mathrm{~mm}$

$\mathrm{T}=119082,45 \mathrm{~N} . \mathrm{mm}$

Dari perhitungan di atas, dapat dibandingkan hasil dari torsi $(\mathrm{T})$ yang terjadi dengan asumsi torsi yang digunakan sebelumnya yaitu:

119082,45 N.mm : 153 N.mm

dengan perbandingan gaya yang digunakan $(\mathrm{F})$ : $4669,90 \mathrm{~N}: 6 \mathrm{~N}$

\section{Bantalan}

Bantalan yang akan digunakan pada redesain mesin pencetak pelet maggot ada 3 macam yaitu jenis bantalan gelinding yang membawa beban aksial dan juga jenis bantalan gelinding yang membawa beban radial. Adapun perhitungan bantalan sebagai berikut:

1. Perhitungan beban ekivalen dinamis

$\mathrm{X}=0,56$

$$
\operatorname{Pr}=\text { X.V.Fr. }+ \text { Y.F } \alpha
$$

$\mathrm{V}=1$ (untuk pembebanan pada cincin dalam yang berputar) 
$\mathrm{Fr}=21 \mathrm{Kg}($ Beban tarik sabuk $)$

$\mathrm{Y}=1,45$

$\mathrm{Fa}=4669,90 \mathrm{~N} / 476,52 \mathrm{Kg}$ (Gaya aksial pada ekstruder)

Nilai $X$ dan $Y$ didapatkan pada referensi

$$
\begin{aligned}
\operatorname{Pr} & =X \cdot V \cdot F r .+Y \cdot F \alpha \\
& =0,56 \cdot 1 \cdot 21+1,45 \cdot 476,52 \\
& =11,76+690,95 \\
& =702,714 \mathrm{Kg}
\end{aligned}
$$

2. Faktor kecepatan putaran bantalan

$$
f n=\left(\frac{33,3}{n 2}\right)^{\frac{1}{3}}
$$$$
\mathrm{n} 2=500 \quad \mathrm{rpm} \text { (putaran yang }
$$
direncanakan)

$f n=\left(\frac{33,3}{500}\right)^{\frac{1}{3}}$

$f n=(0,0666)^{\frac{1}{3}}$

$f n=0,405$

3. Faktor umur bantalan

Ada 3 jenis bantalan yang digunakan yaitu jenis pillow block, ball bearing biasa dan thrust bearing. Oleh karena itu, untuk faktor umur bantalan dipisahkan menjadi 3 berdasarkan jenis dan tipe bantalan.

\section{a. Pillow Block}

Menggunakan jenis bantalan dengan nomor bantalan 6205 Bantalan ini yang menerima beban radial.

$$
\begin{gathered}
f_{h=f n \frac{c}{p}} \\
\mathrm{C}=1100 \mathrm{Kg} \\
\mathrm{P}=702,714 \mathrm{Kg} \\
\mathrm{Fn}=0,405 \\
\quad f_{h=f n \frac{c}{p}} \\
\quad f_{h=0,405 \frac{1100}{702,714}} \\
\quad f_{h=0,405 \cdot 1,56} \\
f_{h=} 0,63
\end{gathered}
$$

b. Ball Bearing Biasa

Menggunakan jenis bantalan dengan nomor bantalan 6005 Bantalan ini yang menerima beban aksial.

$$
\begin{aligned}
& f_{h=f n \frac{c}{p}} \\
& \mathrm{C}=790 \mathrm{Kg} \\
& \mathrm{P}=702,714 \mathrm{Kg} \\
& \mathrm{Fn}=0,405
\end{aligned}
$$

$$
\begin{gathered}
f_{h=f n \frac{c}{p}} \\
f_{h=0,405 \frac{790}{702,714}} \\
\quad f_{h=0,405 \cdot 1,12} \\
f_{h=} 0,45 \\
\text { c. Thrust bearing }
\end{gathered}
$$

Selain kedua bearing diatas, digunakan juga thrust bearing dengan nomor bantalan 51107 yang ditempatkan pada pangkal poros ekstruder sebagai tumpuan dorongan. Bantalan ini yang menerima beban aksial.

$$
\begin{gathered}
f_{h=f n \frac{c}{p}} \\
\mathrm{C}=20400 \mathrm{~N} / 2081,63 \mathrm{Kg} \\
\mathrm{P}=702,714 \mathrm{Kg} \\
\mathrm{Fn}=0,405 \\
\quad f_{h=f n \frac{c}{p}} \\
\quad f_{h=0,405 \frac{2081,63}{702,714}} \\
f_{h=0,405 \cdot 2,96} \\
f_{h=} 1,19
\end{gathered}
$$

4. Umur nominal bantalan $L h=500 f_{h}^{3}$

$$
\begin{aligned}
& \text { a. Pillow Block } \\
& \begin{aligned}
F h & =0,63 \\
\text { Lh } & =500 \cdot(0,63)^{3} \\
& =500 \cdot 0,25 \\
& =125 \mathrm{jam}
\end{aligned}
\end{aligned}
$$

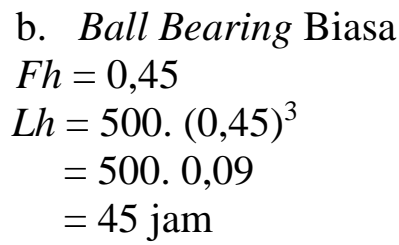

$$
\begin{aligned}
& \text { c. Thrust Bearing } \\
& \begin{aligned}
\text { Fh } & =1,19 \\
\text { Lh } & =500 .(1,19)^{3} \\
& =500.1,68 \\
& =840 \mathrm{jam}
\end{aligned}
\end{aligned}
$$

Untuk perhitungan bantalan digunakan juga rumus referensi dari katalog pabrikan yang akan digunakan yaitu merk FBJ

\section{KESIMPULAN DAN SARAN}




\section{Kesimpulan}

Adapun kesimpulan dari hasil pembuatan mesin pencetak pelet maggot yang telah dilakukan adalah sebagai berikut.

1. Komponen-komponen beserta ukuran yang digunakan pada mesin pencetak pelet maggot berdasarkan perencanaan dan ketersediaan bahan di pasaran.

2. Menggunakan motor bensin dengan daya sebesar 5,5 HP dengan putaran maksimum sebesar $3600 \mathrm{Rpm}$. Untuk putaran motor dapat di setting sesuai kebutuhan tergantung beban adonan yang masuk.

3. Sabuk yang digunakan adalah sabuk-v tipe A dengan nomor 73 untuk menghubungkan poros motor dengan poros extruder sedangkan untuk tipe A dengan nomor 33 digunakan untuk menghubungkan poros extruder dengan poros luar serta poros pemotong.

4. Ukuran puli yang digunakan yaitu sebesar 12 inchi sejumlah 1 buah dan ukuran 4 inchi sejumlah 4 buah dimana ukuran tersebut disesuaikan dengan ukuran yang terdapat di pasaran.

5. Extruder yang digunakan memiliki ukuran panjang total $300 \mathrm{~mm}, \varnothing$ mayor $=$ $51 \mathrm{~mm}$ dan $\emptyset$ minor $=42 \mathrm{~mm}$, jarak antar puncak berturut-turut sebesar 45 $\mathrm{mm}, 29 \mathrm{~mm}$, dan $18 \mathrm{~mm}$. Sedangkan untuk barrel memiliki $\emptyset$ luar $=$ $72 \mathrm{~mm}$ dan $\emptyset$ dalam $=60 \mathrm{~mm}$

6. Terdapat 3 jenis bantalan yang digunakan yaitu jenis bantalan terbuka dengan nomor 6005 yang memiliki diameter dalam sebesar $25 \mathrm{~mm}$, jenis pillow block dengan nomor 6205-16 yang memiliki diameter dalam sebesar 25,4 mm/1 inchi, dan jenis thrust bearing dengan nomor 51107 yang memiliki diameter dalam sebesar $35 \mathrm{~mm}$.

7. Menggunakan rangka besi siku dengan ukuran $40 \mathrm{~mm}$ x $40 \mathrm{~mm}$ x $3 \mathrm{~mm}$ yang dibentuk sedemikian rupa sesuai dengan desain yang dibuat sebelumnya.

8. Menggunkan mur dan baut sejumlah 4 buah pada dudukan motor dan 8 buah pada unit extruder set.

9. Untuk komponen-komponen statis seperti hopper in, hopper out dan penutup v-belt sambungan yang digunakan adalah sambungan keling/rivet dengan ukuran paku keling sebesar $8 \mathrm{~mm}$.

\section{Saran}

Adapun saran yang perlu diperhatikan dalam mesin pencetak pelet maggot ini adalah sebagai beirkut :

1. Jika menggunakan motor listrik, diperlukan pemanas tambahan seperti band heater untuk membuat sistem ekstrusi mencapai suhu kerjanya lebih cepat. Komponen tersebut merupakan pemanas elektrik yang ditempatkan pada barrel, berfungsi untuk pemanas awal agar saat pertama adonan masuk sudah mendapatkan perlakuan panas sehingga pelet pertama yang dikeluarkan langsung bisa mengapung tanpa harus menunggu sistem ekstrusi mencapai suhu kerjanya.

2. Untuk motor listrik, diperlukan reducer/gearbox dengan perbandingan 1:40 atau 1:60 agar memaksimalkan proses yang bekerja.

3. Diperlukan bahan rangka yang lebih kuat agar tidak terlalu menimbulkan getaran.

4. Pastikan semua sambungan kuat dan rapat terutama pada bagian hooper in agar tidak terjadi kebocoran adonan.

5. Perlunya peredam getaran pada bagian alas rangka untuk mencegah mesin bergerak atau berpindah tempat pada saat beroperasi.

\section{REFERENSI}

Agustianti, F. 2016. Gasifikasi Limbah Tempurung Kelapa Sebagai Gas Bakar Pada Motor Bakar Empat Tak [Doctoral Dissertation]. Palembang. Politeknik Negeri Sriwijaya.

Emma, Z. 2006. Studi Pembuatan Pakan Ikan dari Campuran Ampas Tahu,Ampas Ikan, Darah Sapi Potong, dan Daun Keladi yang Disesuaikan dengan StandarMutu Pakan Ikan. Jurnal Sains Kimia 10: 4045.

Fahmi, M. R., Hem, S., \& Subamia, I. W. 2007. Potensi maggot sebagai sumber protein alternatif. In Prosiding Seminar Nasional Perikanan II. Yogyakarta. UGM. 
Gere, J. M., \& Timoshenko, S. P. 2000. Mekanika Bahan. - Ed. 4. - Jakarta: Erlangga.

Li, Q., Zheng, L., Qiu, N., Cai, H., Tomberlin, J. K., \& Yu, Z. 2011. Bioconversion of dairy manure by black soldier fly (Diptera: Stratiomyidae) for biodiesel and sugar production. Waste management, 31(6), 1316-1320.

Nainggolan, H., \& Herman, D. 2017. Analisa Alat Pembuat Pellet Berdasarkan Kapasitas Alat Dan Kemampuan Pisau. Jurnal Teknik Mesin, 6(2), 108-116.

Sularso dan Suga, K. 2004. Dasar Perencanaan dan Pemilihan Elemen Mesin. - Cet. 11. - Jakarta: PT. Pradnya Paramita.

Zaenuri, R., Suharto, B., \& Haji, A. T. S. 2014. Kualitas pakan ikan berbentuk pelet dari limbah pertanian. Jurnal Sumberdaya Alam dan Lingkungan, 1(1), 31-36.

Zainuri, A. M. 2008. Kekuatan Bahan. - Ed. 1. Yogyakarta: CV. Andi Offset. 